\title{
Investigating the Factors that Impact Online Shopping and Sales Promotion on Consumer's Impulse Buying Behavior: A Gender-based Comparative Study in the UAE
}

\author{
Najma Umar Karim \\ Bath University, Bath, UK
}

\author{
Noor un Nisa* \\ Bath University, Bath, UK
}

\author{
Syed Shahid Imam \\ Bath University, Bath, UK
}

\begin{abstract}
An impulse purchase is an important phenomenon for researchers in consumer behavior or buying decision. This paper aims to determine the comparative influence of consumers on online shopping and sales promotion based on gender in the UAE. The survey questionnaire was conducted by online Google form, and 70 respondents were targeted, but only 46 were returned. 24 respondents were females, and 22 were males. A quantitative data collection method was used, and the data analysis demonstrates that online shopping and sales promotion tools impact consumer behavior. Internet shopping is catching people's interest worldwide, although it is early in most countries. The world is moving towards online shopping, but the shift is at different stages, and its penetration varies from nation to nation. Online shopping has been adopted quite well in the developed countries, and it has been noticed that people in developing countries still prefer shopping at physical stores and shopping centers. We are trying to examine why online shopping is still not so strong in a market like the United Arab Emirates (UAE) compared to a developed market like the United States of America (USA). We are explicitly trying to study consumers' behavior towards online shopping in the UAE (Saxena, 2019). Impulse buying grows year on year as sales promotion activities influence consumers and encourage them into unplanned purchases. This research is also trying to study the role of gender on impulse buying. Many researchers have attempted to prove that female buyer are more impulsive buyers. We have attempted to analyze this aspect. The research has tried to study the impulse buying behavior of consumers in the UAE.
\end{abstract}

Keywords: Impulse buying, buying behaviour, online shopping, sales promotion, gender

Received: 13 January 2021; Accepted: 18 March 2021; Published: 26 June 2021

\section{INTRODUCTION}

The UAE is known for its two greatest urban networks, Dubai and Abu Dhabi, which draw countless guests consistently. Dubai, a common business place-point known for its smooth elevated structures, is home to the greatest structure on earth - the Burj Khalifa. Abu Dhabi is the seat of the Federal National Council and fills in as the national capital of the UAE (Bressolles, Durrieu, \& Giraud, 2007). With the development of the innovation of the web, shoppers' purchasing conduct has changed drastically, and new shopping propensities have advanced bit by bit during the last few decades. Lubis (2018) states that human conduct has changed drastically faster because of a steady and quicker web. The older step-by-step process of a product demonstration to negotiation and sales transaction has become much quicker with a compressed period. The retail advertisers are having new and complex considerations related to the new electronic commerce space. Nowadays, web-based shopping mode is becoming increasingly well known due to comfort and solace customers get in sitting at home and engaging in great shopping. (Kannaiah \& Shanthi, 2015) feel

${ }^{*}$ Correspondence concerning this article should be addressed to Noor un Nisa, Bath University, Bath, UK. E-mail: noorbaloch60@gmail.com 
that, albeit numerous customers are moving towards web stores, yet at the same time everywhere, shoppers would also want to shop legitimately from the physical stores (Saxena, 2019).

\section{Online Shopping}

Internet is changing how shoppers shop and purchase items, and it has quickly advanced into a worldwide wonder. Internet-based shopping is the way to purchase merchandise from vendors who sell on the internet. Customers visit the internet stores from the comfort of their homes and shop as they sit before the PC. Purchasers' conduct towards internet-based shopping is a field of enthusiasm for any researcher and domain experts since the internet has incredibly affected consumers' impulse buying and purchasing behavior (Parmar \& Chauhan, 2018).

Regardless of whether shoppers end up in an offline or internet-based buying situation, the dynamics are comparable and exciting at the same time. From need identification to evaluating available choices, assessing various offers, deciding to purchase a specific product, and lastly, expressing post-purchase feedback can be observed and analyzed (Katawetawaraks \& Wang, 2011; Kang \& Ogawa, 2017). Ultimately, the advertisers have to appeal to the customers and convince them to choose their brand (Koo, Kim, \& Lee, 2008).

\section{Sales Promotion}

The influence of sales promotion on impulse buying behavior was presented by Zulfiqar, Ambreen, and Bushra (2018). Promotional activities such as coupons, price promotion, discounts, free products, various schemes, bonus packs, loyalty programs, contests, price packs, and promotional signage affect the impulse buying behavior of consumers. According to Nagadeepa, Selvi, and Pushpa (2015) the definition of sales promotion is an activity that acts as a direct inducement, offering added value or incentive for a product to resellers, salespersons or customers". It also explained sales promotion as special offers which essentially aim to stimulate demand for the products. However, in this study, sales promotion is described as products offered in deals and discounts. It becomes economical for customers when discounts and deals are available at supermarkets. During events and activities, products available at a price lower than actual are included in sales promotion. Sales promotion is encouraged by marketers to attract customers towards their brands resulting in the switching of brands by customers (Apriliani, 2018; Memon, Kazi, Zubedi, \& Ansari, 2019).

\section{Contribution of the Researcher}

The research examines and gathers quantitative data and how the factors of impulse purchase impact online shopping and sales promotion by a comparative study on gender in the UAE. This research will also help understand the impact of impulse buying on consumer behavior, increasing day by day.

\section{Research Objectives}

- To investigate the impact of impulse buying behavior on online shopping of consumers in the UAE.

- To study impulse buying behavior and its impact on sales promotions.

- To explore the factors that encourage impulse buying decisions of consumers for online shopping in the UAE.

- To analyze the impact of online shopping and sales promotion on consumer's impulse buying behavior.

\section{LITERATURE REVIEW}

\section{Consumer Behavior}

The consumer is the king in the business and plays a very important role in every business. in business, to know the consumer behavior significance and hard activity. To define consumer behavior, Schiffman, Kanuk, and Wisenblit (2010) explains that "the behavior that consumers display in searching for, purchasing, using, evaluating, and disposing of products and services that they expect will satisfy their needs" this is significant to know the consumer behavior, especially for marketers to run any business (Parmar \& Chauhan, 2018).

\section{Impulse Buying}

Impulse purchasing can be characterized as a happening when customers feel an unexpected, regularly amazing desire to purchase something at the earliest opportunity. The desire to purchase is a complex libertine procedure and may emerge an enthusiastic clash. "Also, impulse buying is prone to occur with diminished regard for its consequences" (Rook \& Hoch, 1985). The term" impulse buying" mentions a smaller and more explicit scope of wonders than 
unplanned purchasing. All the more critically, it recognizes a mentally particular sort of conduct that contrasts significantly from the thoughtful method of buyer decision. Impulse purchasing is commonly known for consumer's spontaneous buy which turns into a significant piece of the buyer's conduct, it represents $62 \%$ of sales of the general store and $80 \%$ of certain item categories" sales (Hole, Pawar, \& Khedkar, 2019).

"An Impulse purchase is a powerful, unintended, sudden, emotional and persistent urge which occurs spontaneously" (Karbasivar \& Yarahmadi, 2011) and (Sultan, Joireman, \& Sprott, 2012). "An Impulse purchase is defined as buying the items that are not in your planned shopping list" (Jeffrey \& Hodge, 2007). "An Impulse purchase is an urge that can arise around the clock and is hard to resist. It comprises the unreflective and spontaneous desire to purchase things without any logical or thoughtful process". "The results are composed of determinants, dimensions and outcomes of impulse buying" (Zulfiqar et al., 2018). As indicated by this investigation, shopping anything with no earlier goal to shop is fulfilling, where an individual needs to consider the upsides and downsides of purchasing a specific item. An individual needs to inspire himself to shop out-of-the-rundown things. It gives a sentiment of more prominent confidence that an individual feels sure, autonomous without any limitations to shop prompts drive purchasing (Memon et al., 2019).

\section{Types of Impulse Buying}

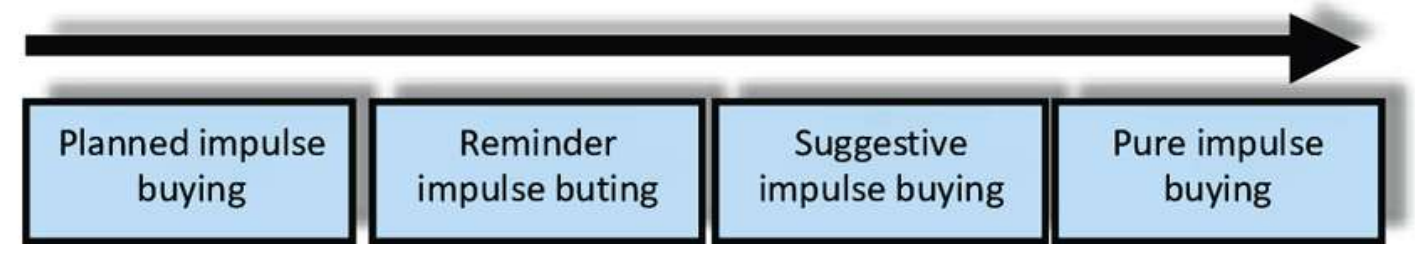

Figure 1 Types of Impulse Buying

\section{Significance of Impulse Buying of Consumer Behavior}

As indicated by this investigation, shopping anything with no earlier goal to shop is fulfilling, where an individual needs to consider the upsides and downsides of purchasing a specific item. An individual needs to inspire himself to shop out-of-the-rundown things. It gives a sentiment of more prominent confidence that an individual feels sure, autonomous without any limitations to shop prompts impulse purchasing (Aragoncillo \& Orus, 2018).

Background of impulse buying behavior market: A huge piece of the world's economy is driven by impulse buying. A larger piece of that spending relies upon things we generally need, like food, clothing, and shelter. The normal spending or things we would incline toward need yet not to have can cause an economy to create or fall apart quickly! Nothing drives discretionary spending like inspiration buying-over $90 \%$ of individuals who make online motivation purchasing didn't intend to buy from the outset.

- A 2011 examination demonstrated that 6 out of 10 women and made one significant drive buy inside the most recent year in any event.

- Men may not purchase more regularly than women, yet they will burn through 41 per impulse buy contrasted with 31 per buy for ladies.

By statistics of online impulse purchasing being half or more in about each segment, it is anything but difficult to perceive how the sights, sounds, and scents of a physical store can impact the dynamic procedure. If you've at any point been out shopping and smelled something superb, at that point, you realize how obvious that can be! Even though it isn't tricky, understand that it can transform into one .

The behavior of impulse buying consumers: As indicated by the investigation directed by MasterCard Worldwide Index in Consumer Confidence, Indian buyers were positioned as one of the most certain about the world. This brought about a lift in the utilization and acquisition of fundamental and extra items. Another significant trademark regarding Indian purchasers is that the dominant part of the populace includes youth who are profoundly experimented with and are inclined to drive purchasing, as indicated by the KPMG study, 2014. The early adopters rashly purchase new items and attempt new brands with no related knowledge. Impulse purchasing can be characterized as a purchaser's propensity to purchase products and enterprises with no arranging. Distinctive purchasing circumstances lead to various impulses of purchasing conduct. Along these lines, we can characterize impulse purchasing as an unconstrained response to 
purchasing the items absent from data checking or information preparation. While making impulsive purchasing, shoppers are in a mood that they are not considering the item or not looking at it. Here shopping can be depicted as a passionate state of mind upgrade action with the choice to follow up spontaneously in the wake of seeing the item in the retail outlet (Mathai \& Shanthaamani, 2016).

Impact of impulse buying on consumer behavior: Even though the genuine impact of the monetary conflicts and the creating usage of the internet as information search and purchase channel, buyer direct seems to have changed towards a logically organized and taught technique (Banjo \& Germano, 2014). At the same time, a couple of makers ensure that the internet, in all actuality, favors impulse purchasing. "Simultaneously, a few creators guarantee that the internet, in reality, favors impulse buying" (Aragoncillo \& Orus, 2018).

Gender: Gender is the social differentiation among ladies and men, their jobs, and developing the general public. It is found as a key determinant in drive purchasing practices. A few investigations pronounce that ladies are increasingly fast in purchasing when contrasted with men. While the others keep up that men show more drive buying than ladies. For the most part, men don't accept delight in getting as much as ladies regularly do; this decreases the odds of settling on imprudent decisions among men people. Men regularly have the least communication in common shopping however are genuinely master at obtaining strong merchandise, similar to autos, instruments, sound systems or PC frameworks and so on., while women generally deal with increasingly flashing things, such as preparing a supper, embellishing a cake, right hairstyle or cosmetics and so on. For young ladies, shopping is a sort of revamping mastery and has mental and enthusiastic affiliation that once in a while exists in guys. It was dissected that female shoppers' purchasing conduct was effortlessly affected by publicizing, showcases of merchandise, environment, advancements, deals, and the perspectives of the sales rep. For the most part, ladies get self-expressive and emblematic stuff that speaks to their passionate angles and appearance. In this manner, young ladies have a bigger inclination to purchase incautiously, and for guys, the indiscreet shopping propensity is a greater amount of instrumental character. They will, in general, find what they need and end it rapidly with an insignificant degree of commitment. Incautious purchasing for them is, in this way, a quicker choice and also the speediest feasible use of the merchandise purchased. In addition, for guys, indiscreet shopping inclination is progressively related to features of cash perspectives (Akram, Hui, Khan, Hashim, \& Rasheed, 2016).

\section{RESEARCH METHODOLOGY}

Means of research are given by Creswell and Creswell (2017), who communicates that - "Research is a technique of steps used to assemble and dismember information to construct our perception of a point or issue." It contains three phases: Pose a question, assemble data to react to it, and present a reaction to the questions (Creswell \& Creswell, 2017). Research technique is the route by which experts need to lead their investigation. It shows how these researchers plan their uneasiness and goal and present their outcome from the information got during the assessment period (Sileyew, 2019).

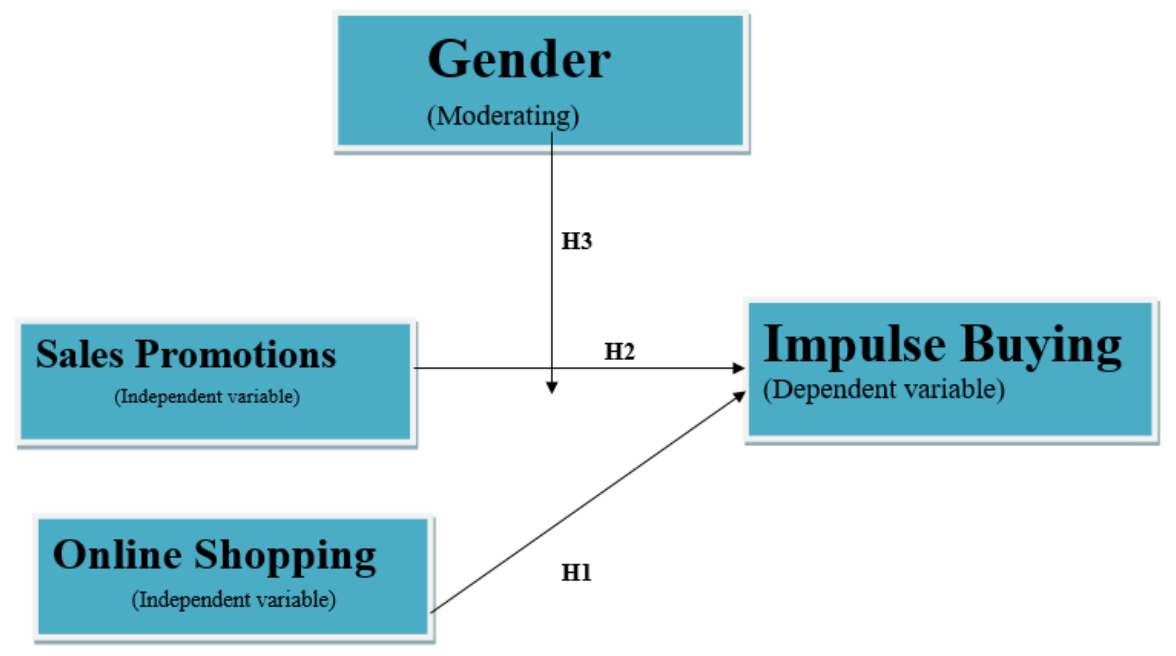

Figure 2 Conceptual Framework 
H1: The positive and negative relationship between impulse buying and online shopping.

H2: The positive and negative relationship between impulse buying and online shopping.

H3: The positive and negative relationship between impulse buying and gender.

\section{Research Settings}

To conduct this study researcher utilized mono-strategy (quantitative) by using a questionnaire. "The questionnaires consist of closed-ended questions; makeup fixed response answers to be selected, and some, other space specified for the respondent(s) to factor any alternative answer(s) of their own choice" (Malhotra \& Birks, 2003). Essentially, the analysts utilized the organized, planned review survey to get data of the shopper's involvement in the motivation purchasing. The research investigated the impacts of impulse buying behavior of consumers in terms of online shopping and sales promotions: A comparative study on gender in UAE. The research included both gender males and females, and the age was selected from 20 to 49 respondents. No specific place was selected for this research because the survey was distributed on an online platform, but the country was the UAE. The sampling method which researcher uses was simple random sampling for the participants selected for this research. In probability sampling, the elements are selected randomly. The population selected for this research was the general public, and there is no specific population group targeted.

The researcher utilizes the impulse purchasing behavior scale to examine the information and give dependable data for this investigation. The Likert scale helped determine the factors that impact impulse buying behavior in terms of online shopping and sales promotions.

\section{RESULTS}

\section{Reliability Test}

Cronbach's alpha is the most generally perceived extent of inside consistency ("unfaltering quality"). It is most customarily used when you have distinctive Likert requests in a survey/survey that structure a scale and you wish to choose whether the scale is reliable. If you are stressed over between rater immovable characteristics, we furthermore have a guide on using Cohen's () kappa that you may find significant.

The reliability test for all variables is shown in the Table below;

Table 1 RELIABILITY STATISTICS

\begin{tabular}{lll}
\hline Variable & Cronbach's Alpha & N of Items \\
\hline Sales Promotions & .950 & 4 \\
Online Shopping & .923 & 5 \\
Impulse Buying & .984 & 10 \\
\hline
\end{tabular}

The two arrangements of inquiries are comparable and have a similar unwavering quality proportion of alpha rising to .82. Most of the inquiries are worded with minor departure from the topic of purchasing things unexpectedly, with a couple of differentiating inquiries concerning cautiously arranging buys.

In the reliability test, Cronbach's Alpha has been tested for the number of items in the Table 1 for each variable. The Cronbach's for Sales Promotions of 4 items is .950, for Online shopping for five items the Cronbach's Alpha is .923 and lastly for Impulse buying for 10 items the Cronbach's Alpha is .984 , which is shown that the data which respondents collect is reliable and useful.

\section{Frequency Test}

The Frequencies system can create outline measures for clear cut factors as recurrence Tables, bar diagrams, or pie graphs. 
Table 2 FREQUENCY TEST FOR DEMOGRAPHIC INFORMATION

\begin{tabular}{lllllll}
\multicolumn{2}{l}{ Statistics } & & & & \\
& & Gender of Respondents & Age group & Education & Occupation & Marital Status \\
\hline \multirow{2}{*}{ N } & Valid & 46 & 46 & 46 & 46 & 46 \\
& Missing & 0 & 0 & 0 & 0 & 0 \\
\hline
\end{tabular}

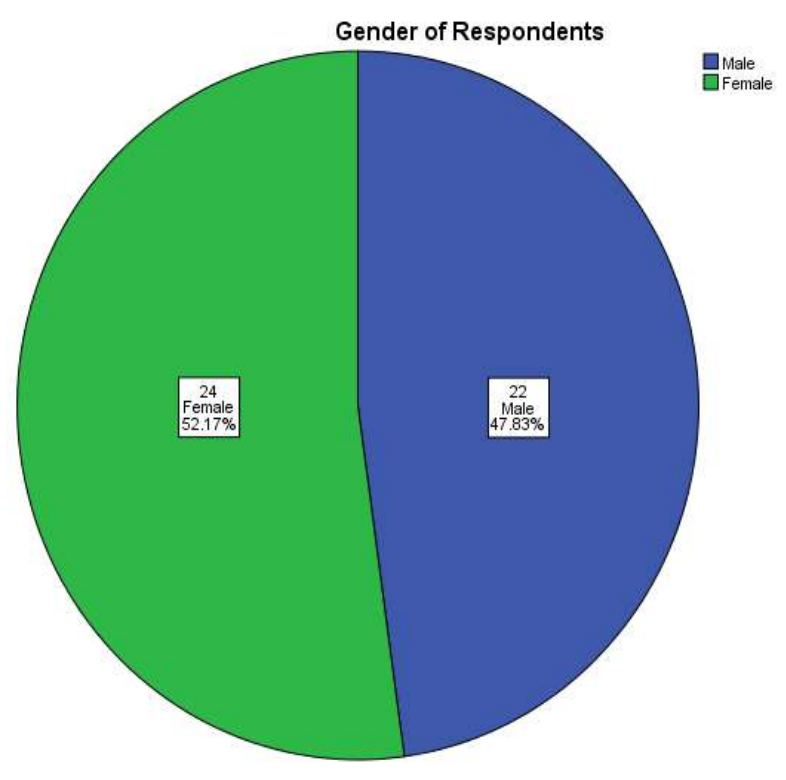

Figure 3 Gender of Respondents

By Frequency test in the above pie chart shows that 46 respondents were targeted for the survey questionnaire. The total number of respondents was 46 , the 22 were males, and the total percentage is $47.83 \%$ in that the 24 were females, and the percentage was $52.17 \%$ included in this research.

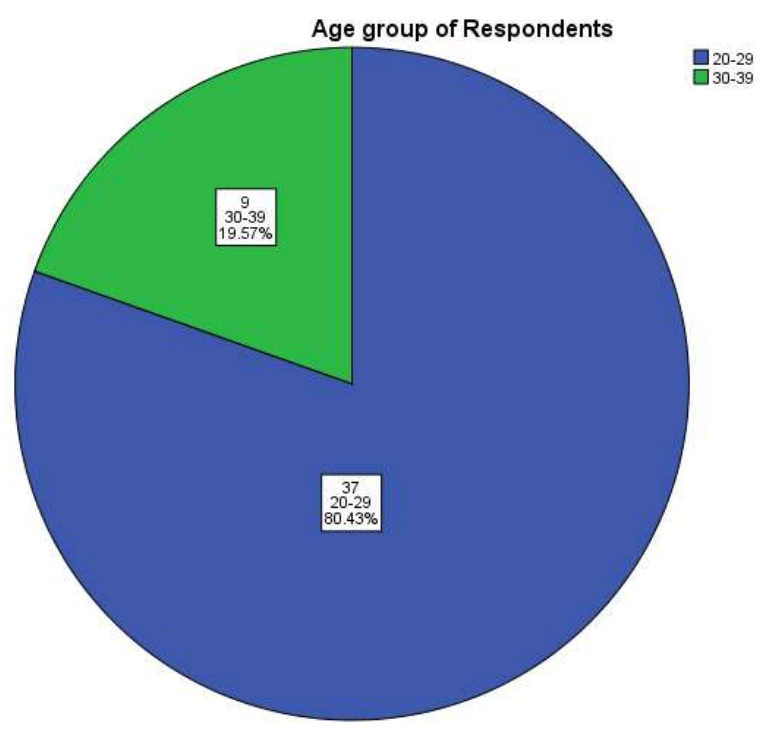

Figure 4 Age Group of Respondents 
In the questionnaire survey, the age was targeted from 20-29, 30-39, and 40-49 was selected for the respondents. In the above pie chart, 37 respondents surveyed the age of 20-29, which is (80.43\%). The left 6 respondents surveyed the age of $30-39$, and the percentage is $(19.57 \%)$.

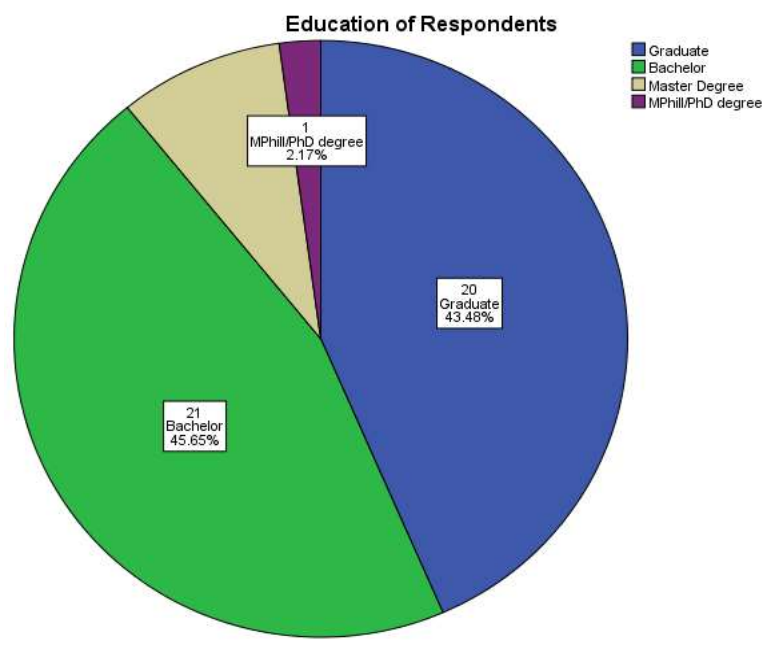

Figure 5 Education Status of Respondents

The above pie chart also shows that the survey questionnaire conducted by respondents was mostly Graduate and Bachelor. The following list can show the education of respondents. The 20 respondents were graduates, and the percentage is $(43.48 \%)$. The 21 respondents were Bachelor, and the percentage is shown is $(45.65 \%)$. The one respondent was Mphil/Ph.D. degree pass and a percentage is $(2.17 \%)$.

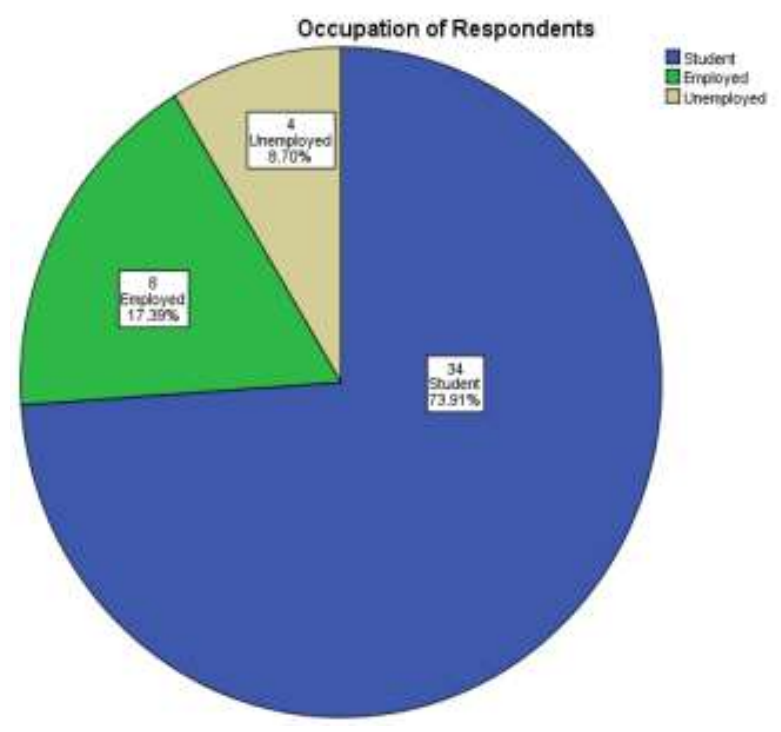

Figure 6 Occupation of Respondents

This pie chart describes that the Occupation of Respondents is mostly students, which is 34 and the percentage is $(73.91 \%)$. The eight respondents were employed, and the percentage is shown is $(17.39 \%)$. Lastly, the 4 were unemployed, and the percentage is $(8.70 \%)$. 


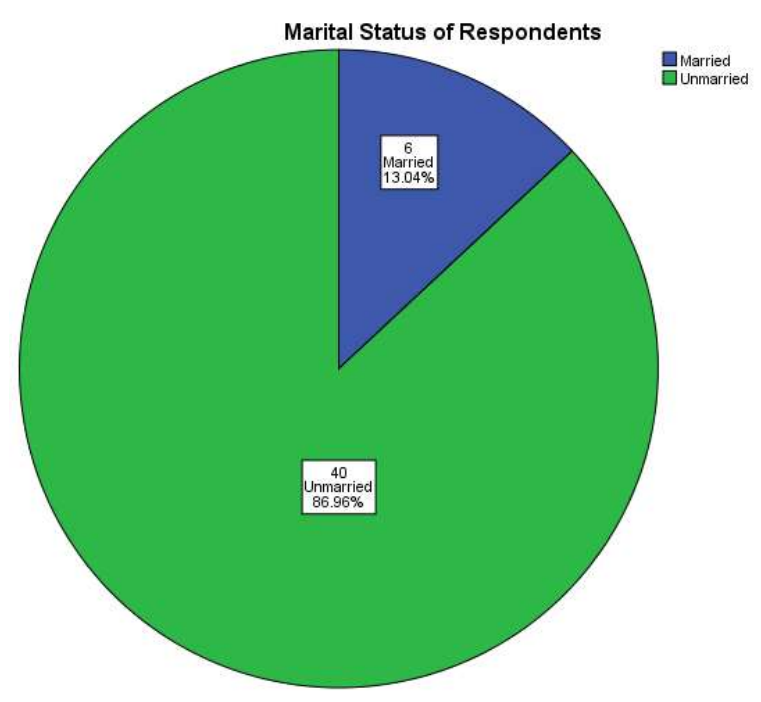

Figure 7 Marital Status of Respondents

This pie chart shows the marital status of respondents, and most of the respondents were unmarried. The number of unmarried respondents is 40 , and the percentage is $(86.96 \%)$. The married respondents were 6 , and the percentage is $(13.04 \%)$.

\section{Correlation Test}

Correlations are a factual procedure that shows how emphatically two factors are identified with one another or the level of relationship between the two. For instance, on the off chance that we have the weight and tallness information of taller and shorter individuals, we can discover how these two factors are connected with the connection between them. We can likewise discover the relationship between's these two factors and state that their loads are decidedly identified with stature. The relationship is estimated by the connection coefficient.

Table 3 CORRELATION

\begin{tabular}{lllll}
\hline & & & & \\
& & Online Shopping & Sales Promotions & Impulse Buying \\
\hline \multirow{2}{*}{ Online Shopping } & Pearson Correlation & 1 & $.957 * *$ & $.962^{* *}$ \\
& Sig. (2-tailed) & & .000 & .000 \\
& $\mathrm{~N}$ & 46 & 42 & 43 \\
Sales Promotions & Pearson Correlation & $.957 * *$ & 1 & $.943^{* *}$ \\
& Sig. (2-tailed) & & .000 & .000 \\
Impulse Buying & $\mathrm{N}$ & 42 & 42 & 42 \\
& Pearson Correlation & $.962 * *$ & $.943 * *$ & 1 \\
& Sig. (2-tailed) & & .000 & .000 \\
& $\mathrm{~N}$ & 43 & 42 & 43 \\
\hline
\end{tabular}

**. Correlation is significant at the 0.01 level (2-tailed).

The above Table shows that there is a positive correlation with each other, which means the hypothesis of impulse buying correlates with sales promotions and online shopping, which gives the significant correlation in the above Table. 


\section{Regression Test}

Multiple regressions incorporate a group of procedures that can be utilized to investigate the connection between one persistent ward variable and various autonomous factors or indicators.

Table 4 REGRESSION IMPULSE BUYING VS. SALES PROMOTIONS

\begin{tabular}{llllll}
\multicolumn{5}{c}{ ANOVA $^{a}$} \\
\hline Model & Sum of Squares & $d f$ & Mean Square & $F$ & Sig. \\
\hline Regression & 5710.651 & 1 & 5710.651 & 319.491 & $.000^{b}$ \\
Residual & 714.968 & 40 & 17.874 & & \\
Total & 6425.619 & 41 & & &
\end{tabular}

a. Dependent Variable: Impulse Buying

b. Predictors: (Constant), Sales Promotions

\begin{tabular}{|c|c|c|c|c|c|}
\hline \multicolumn{6}{|c|}{ Coefficients $^{a}$} \\
\hline \multirow[t]{2}{*}{ Model } & \multicolumn{2}{|c|}{ Unstandardized Coefficients } & Standardized Coefficients & \multirow[t]{2}{*}{$t$} & \multirow[t]{2}{*}{ Sig. } \\
\hline & B & Std. Error & Beta & & \\
\hline 1 (Constant) & 1.918 & 1.486 & & 1.290 & .204 \\
\hline Sales Promotion & 3.042 & .137 & .958 & 22.153 & .000 \\
\hline
\end{tabular}

a. Dependent Variable: Impulse Buying

Here we tested the hypothesis of impulse buying and sales promotion to see that they relate to each other positively, for we did a regression test. So after getting results, it is proved that impulse buying significantly relates to sales promotion. Impulse buying impact when the sales promotions increase or decrease, and the researcher use multi regression test to see the affective relationship between two variables. It shows that the independent variables in the Table of ANOVA $F(1,4)=319.491, p<.0005$, which significantly predict the dependent variables.

Table 5 REGRESSION IMPULSE BUYING VS. ONLINE SHOPPING

\begin{tabular}{llllll}
\multicolumn{7}{c}{ ANOVA $^{a}$} \\
\hline Model & Sum of Squares & $d f$ & Mean Square & $F$ & Sig. \\
1 Regression & 7043.420 & 1 & 7043.420 & 504.677 & $.000^{b}$ \\
Residual & 572.208 & 41 & 13.956 & & \\
Total & 7615.628 & 42 & & & \\
\hline
\end{tabular}

a. Dependent Variable: Impulse Buying

b. Predictors: (Constant), Online Shopping 


\begin{tabular}{|c|c|c|c|c|c|}
\hline \multicolumn{6}{|c|}{ Coefficients $^{a}$} \\
\hline \multirow[t]{2}{*}{ Model } & \multicolumn{2}{|c|}{ Unstandardized Coefficients } & \multirow{2}{*}{$\begin{array}{l}\text { Standardized Coef- } \\
\text { ficients } \\
\text { Beta } \\
\end{array}$} & \multirow[t]{2}{*}{$t$} & \multirow[t]{2}{*}{ Sig. } \\
\hline & $\mathrm{B}$ & Std. Error & & & \\
\hline 1 (Constant) & 3.865 & 1.346 & & 2.871 & .006 \\
\hline Online Shopping & 3.056 & .108 & .974 & 28.415 & .000 \\
\hline
\end{tabular}

a. Dependent Variable: Impulse Buying

The change in the information is separated into many parts. The specialized foundation to an ANOVA table is past the extent of this preliminary. We take a gander at the Sig. Segment, which discloses to us the $p$-value for the $R^{2}$ measurement. If it is higher than 0.05 , at that point, the entire model isn't factually critical, and we have to stop our examination here. The $t$ value is above 1.96, demonstrating that both variables have a positive relationship (Tranmer \& Elliot, 2008).

Table 6 REGRESSION FOR IMPULSE BUYING VS. GENDER

\begin{tabular}{llllll}
\hline \multicolumn{7}{c}{ ANOVA $^{a}$} & & \\
\hline Model & Sum of Squares & df & Mean Square & $F$ & Sig. \\
\hline Regression & 5137.955 & 1 & 5137.955 & 85.022 & $.000^{b}$ \\
Residual & 2477.673 & 41 & 60.431 & & \\
Total & 7615.628 & 42 & & & \\
\hline
\end{tabular}

a. Dependent Variable: Impulse Buying

b. Predictors: (Constant), Online Shopping

Coefficients $^{a}$

\begin{tabular}{|c|c|c|c|c|c|}
\hline \multirow[t]{2}{*}{ Model } & \multicolumn{2}{|c|}{ Unstandardized Coefficients } & \multirow{2}{*}{$\begin{array}{l}\text { Standardized Coef- } \\
\text { ficients } \\
\text { Beta }\end{array}$} & \multirow[t]{2}{*}{$t$} & \multirow[t]{2}{*}{ Sig. } \\
\hline & B & Std. Error & & & \\
\hline (Constant) & 3.641 & 3.724 & .978 & .334 & \\
\hline $\begin{array}{l}\text { Gender of Respon- } \\
\text { dents }\end{array}$ & 21.868 & 2.372 & .821 & 9.221 & .000 \\
\hline
\end{tabular}

a. Dependent Variable: Impulse Buying

The relationship of impulse buying and gender is shown in the above table is positive

\section{RESEARCH ANALYZES AND DISCUSSION}

In the literature, the researcher explains different points of view by giving theories that define impulse buying from different perspectives. The researcher emphasizes the research question that defines the factors that impact impulse buying behavior in terms of online shopping and sales promotions a comparative study on gender in UAE. According to (Jeffrey \& Hodge, 2007), "An Impulse purchase is defined as buying the items that are not in your planned shopping list." 


\section{Significance of Impulse Buying of Consumer Behavior}

The researcher also defines the significance of impulse buying of consumer behavior. A larger piece of that spending relies upon things we generally need, like food, clothing, and shelter. The normal spending or things we would incline toward need yet not to have can cause an economy to create or fall apart quickly! Nothing drives discretionary spending like inspiration buying. Over $90 \%$ of individuals who make online impulse purchasing didn't intend to buy from the outset .

The researcher tests its data using SPSS; the first test conducted is reliability to check that the Cronbach's Alpha has been tested for several items for each variable. The Cronbach's for Sales Promotions of 4 items is .950, for Online shopping for 5 items the Cronbach's Alpha is .923 and lastly for Impulse buying for 10 items the Cronbach's Alpha is .984 , which is shown that the data which respondents collect is reliable and useful. The other test is normality which tests the significant value to see that the survey sample is distributed for each variable to the respondent. The result for hypotheses testing shows that there is a positive correlation with each other and which means the hypothesis of impulse buying correlates with sales promotions and online shopping, which gives the significant correlation in the above table by using correlate test. The researcher also conducted regression to test the hypothesis to see that they are positively related to each other or not. Through regression test, it is proved that impulse buying is positively related to online shopping and sales promotions. It is found that consumers in UAE are more impulsive regarding online shopping and sales promotions when the online shopping and sales promotions increase or decrease its impact on impulse buying of a consumer in UAE.

\section{CONCLUSION}

To conclude, the researcher analyzes that impulse buying consumers in UAE are more impulsive regarding online shopping and sales promotions. It is a positive sign for the marketer to gain more profit in the coming year. In literature, the researcher defines impulse buying through many theories that negatively and positively impact consumers. The consumer plays an important role in business as it purchases different kinds of products online or from the store. Impulse buying is increasing day by day, and the consumer mostly purchases unplanned products when they see the sales promotions.

Further, the researcher explains gender, which is also an important part while discussing impulse buying. Most of the previous researcher indicates that females are more impulsive than true males. The researcher further explains the importance of impulse buying and the impact of consumers' impulse buying behavior. The researcher emphasizes the results tested in SPSS, and the researcher explains the hypothesis. In this research, the researcher discusses 3 hypotheses; the 1st hypothesis is the positive and negative relation between impulse buying and online shopping, the 2 nd is the positive and negative relationship between impulse buying and sales promotions, and the second is the positive and negative relationship between impulse and gender. The researcher discusses the results, which are analyzing in SPSS. In this research, the researcher follows the research onion, proposed by (Saunders \& Townsend, 2016) "is a tool that helps organize the research and develop research design following the layers of the research onion step by step."

\section{Future Study Recommendation}

After the complete audit of the writing and substance investigation, we have inferred a few expectations for future research tries in the field of impulse purchasing. In this research, the researcher proposes a structure to increment the comprehension of impulse purchasing. In the wake of examining the different elements concentrated in the past investigations, we conceptualized four distinct gatherings which could suit the different components. In this way, we have arranged the different factors under the general classes of "Outer boosts," "Inside improvements," "Situational what's more, item related components," and "Socioeconomics and Socio-social elements." We have also watched the different variables affecting impulse purchasing and some directing characteristics, such as discernment and characteristics. Our survey shows that the motivation purchasing results from the association of different inside and outside upgrades. For example, there are angles, character attributes, and socio-social qualities that could be concentrated further in detail to all the more likely comprehend the lack of caution of the shoppers (Muruganantham \& Bhakat, 2013). 


\section{REFERENCES}

Akram, U., Hui, P., Khan, M. K., Hashim, M., \& Rasheed, S. (2016). Impact of store atmosphere on impulse buying behaviour: Moderating effect of demographic variables. International Journal of U-and E-Service, Science and Technology, 9(7), 43-60. doi:https://doi.org/10.14257/ijunesst.2016.9.7.05

Apriliani, H., K. \& Hudrasyah. (2018). The effect of convebtional customer habit: Touch, sight, smell on online written batik fabric. International Journal of Business and Economic Affairs, 3(5), 195-206. doi:https://doi.org/ 10.24088/ijbea-2018-35002

Aragoncillo, L., \& Orus, C. (2018). Impulse buying behaviour: An online-offline comparative and the impact of social media. Spanish Journal of Marketing-ESIC, 22(1), 42-62. doi:https://doi.org/10.1108/SJME-03-2018-007

Banjo, S., \& Germano, S. (2014). The end of the impulse shopper. Retrieved from https://on.wsj.com/3jaY8Eh

Bressolles, G., Durrieu, F., \& Giraud, M. (2007). The impact of electronic service quality's dimensions on customer satisfaction and buying impulse. Journal of Customer Behaviour, 6(1), 37-56. doi:https://doi.org/10.1362/ $147539207 \times 198365$

Creswell, J. W., \& Creswell, J. D. (2017). Research design: Qualitative, quantitative, and mixed methods approaches. Thousand Oaks, CA: Sage publications.

Hole, Y., Pawar, M. S., \& Khedkar, E. (2019). Omni channel retailing: An opportunity and challenges in the Indian market. In International Conference on Physics and Photonics Processes in Nano Sciences, Eluru, India.

Jeffrey, S. A., \& Hodge, R. (2007). Factors influencing impulse buying during an online purchase. Electronic Commerce Research, 7(3), 367-379. doi:https://doi.org/10.1007/s10660-007-9011-8

Kang, C. Z., \& Ogawa, I. (2017). Online shopping behavior of chinese and japanese consumers. Journal of Administrative and Business Studies, 3(6), 305-316. doi:https://doi.org/10.20474/jabs-3.6.5

Kannaiah, D., \& Shanthi, R. (2015). The impact of augmented reality on e-commerce. Journal of Marketing and Consumer Research, 8, 64-73.

Karbasivar, A., \& Yarahmadi, H. (2011). Evaluating effective factors on consumer impulse buying behavior. Asian Journal of Business Management Studies, 2(4), 174-181.

Katawetawaraks, C., \& Wang, C. (2011). Online shopper behavior: Influences of online shopping decision. Asian Journal of Business Research, 1(2), 66-74. doi:https://doi.org/10.14707/ajbr.110012

Koo, D.-M., Kim, J.-J., \& Lee, S.-H. (2008). Personal values as underlying motives of shopping online. Asia Pacific Journal of Marketing and Logistics, 20(2), 156-173. doi:https://doi.org/10.1108/13555850810864533

Lubis, A. N. (2018). Evaluating the customer preferences of online shopping: Demographic factors and online shop application issue. Academy of Strategic Management Journal, 17(2), 1-13.

Malhotra, N., \& Birks, D. (2003). Marketing research: An applied approach. Hoboken, NJ: Prentice Hall.

Mathai, S. T., \& Shanthaamani, V. (2016). Materialism: Its impact on impulse buying behaviour among the retail customers of Cochin. International Journal of Management Research and Reviews, 6(5), 647-658. doi:https://doi.org/10.9756/ijras.8153

Memon, R. H., Kazi, A. G., Zubedi, M. Y., \& Ansari, A. (2019). Factors affecting impulse purchase behavior in hyderabad marketing perspective. International Journal of Entrepreneurial Research, 2(1), 20-24. doi:https:// doi.org/10.31580/ijer.v1i2.506

Muruganantham, G., \& Bhakat, R. S. (2013). A review of impulse buying behavior. International Journal of Marketing Studies, 5(3), 149-160. doi:https://doi.org/10.5539/ijms.v5n3p149

Nagadeepa, C., Selvi, T., \& Pushpa, A. (2015). Impact of sale promotion techniques on consumers' impulse buyıng behaviour towards apparels at Bangalore. Asian Journal of Management Sciences \& Education, 4(1), 116-124.

Parmar, G., \& Chauhan, J. (2018). Factors affecting online impulse buying behaviour. International Journal of Education and Management Studies, 8(2), 328-331.

Rook, D. W., \& Hoch, S. J. (1985). Consuming impulses. In E. C. Hirschman \& M. B. Holbrook (Eds.), Na - advances in consumer research. Provo, UT : Association for Consumer Research.

Saunders, M. N., \& Townsend, K. (2016). Reporting and justifying the number of interview participants in organization and workplace research. British Journal of Management, 27(4), 836-852. doi:https://doi.org/10.1111/1467 $-8551.12182$

Saxena, R. P. (2019). Online shopping behavior in West and Wast: A comparative analysis of USA and UAE shoppers. Academy of Marketing Studies Journal, 23(1), 1-26. 
Schiffman, L. G., Kanuk, L. L., \& Wisenblit, J. (2010). Consumer behaviour: Global edition. Pearson Higher Education, London, 12(2), 113-120.

Sileyew, K. J. (2019). Research design and methodology. London, UK: IntechOpen.

Sultan, A. J., Joireman, J., \& Sprott, D. E. (2012). Building consumer self-control: The effect of self-control exercises on impulse buying urges. Marketing Letters, 23(1), 61-72. doi:https://doi.org/10.1007/s11002-011-9135-4

Tranmer, M., \& Elliot, M. (2008). Multiple linear regression. The Cathie Marsh Centre for Census and Survey Research (CCSR), 5(5), 1-5.

Zulfiqar, J., Ambreen, G., \& Bushra, M. F. (2018). A comprehensive literature review of impulse buying behavior. Journal of Advanced Research in Social and Behavioural Sciences, 11(1), 94-104. 